Bangladesh J. Bot. 41(1): 97-104, 2012 (June)

\title{
ETHNO-MEDICO-BOTANICAL STUDY IN LAWACHARA NATIONAL PARK, BANGLADESH
}

\author{
Mohammad Zashim Uddin*, Md Abul Hassan, Mizanur Rahman \\ and Kamrul Arefin
}

Department of Botany, University of Dhaka, Dhaka-1000, Bangladesh

Key words: Ethno-medico-botanical study, Lawachara National Park, Bangladesh

\begin{abstract}
Use of medicinal plants for primary health care by the local people in and around the Lawachara National Park, Bangladesh was recorded. A total of 56 plant species under 30 families with 70 formularies (treatment mode) have been documented. Among the medicinal species, Citrus limon (L.) Burm. f., C. maxima (Burm.) Merr., Cucurbita pepo L., Lepisanthes rubiginosa (Roxb.) Leenh., Euphorbia pulcherrima Willd. ex Klotz., Mimosa diplotricha C. Wright ex Sauv. have been reported as new medicinal species from Bangladesh. Out of these plant species, 39.29\% belonged to herbs, $19.64 \%$ shrubs, $3.71 \%$ trees and $5.36 \%$ climbers. In majority cases, leaves of the medicinal plants were found leading in terms of their use followed by fruit, bark, stem, seed, whole plant, latex, rhizome and inflorescence.
\end{abstract}

\section{Introduction}

Lawachara National Park under Maulvi Bazar district is a part of West Bhanugach reserve forest, which was declared reserve in early 19th century as per the Forest Act 1878, the Assam Forest Manual 1898 and the Forest Act 1927. It lies between $24^{\circ} 30^{\prime}-24^{\circ} 32^{\prime} \mathrm{N}$ and $91^{\circ} 37^{\prime}-91^{\circ} 39^{\prime}$ E. A part of the reserve forest was declared as a National Park in 1996 having a total area of 1250 ha (Green 1990, Canonizado and Rahman 1998, Riadh 2007, Ahsan 2007). Lawachara forest is a combination of planted exotic species and mixed forest with a deciduous canopy and an evergreen understory (Ahsan 2000). The forest originally supported an indigenous vegetation cover of mixed tropical evergreen type (Alam 1998). Socio-economic and ecological values of the park is high because a number of ethnic (mainly Khasia, approximately 400 people) and other people reside within and around the park on which they depend for their livelihood to some extend. Once, they relied on natural plants and plant products of the park for the primary healthcare other than modern medicine. Currently, traditional knowledge of primary healthcare system of ethnic communities is under great threat because of a number of factors including deforestation, habitat degradation, biodiversity loss and modern civilization. For the sake of conservation of local ethnic knowledge on medicinal plants, ethno-medico-botanical study in Lawachara National Park was essential.

In Bangladesh so far a number of ethno-medico-botanical research has been carried out (Uddin et al. 2001, 2004, 2006, 2008, Khan et al. 2002, Uddin and Roy 2007). But none of them was devoted to ethno-medico-botany of Lawachara National Park. The aim of the present study was to record medicinal knowledge of plants used by the local and ethnic communities living in and around the Lawachara National Park.

\section{Materials and Methods}

The study was carried on the local people living in and around the Lawachara National Park from July, 2009 to June, 2010. A total of 100 people (50 from Khasia community and 50 other than Khasia) having an age range 12 - 92 years were interviewed using semistructured interview

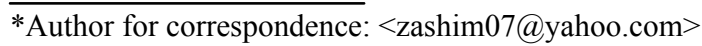


method (Alexiades 1996, Martin 1995). Professionally they were peasant, day labor, betel leaf cultivators, house wives, medicine men, forest minor product collectors, small shop keepers, etc. Among them 35 were female and rest 65 were male. Triangulation method have been followed for data validation in the field (Dean and Whyte 1959). Plant specimens with flowers and fruits were collected and processed using standard herbarium techniques (Hyland 1972, Alexiades 1996). The specimens were identified consulting Uddin and Hassan (2004), Siddiqui et al. (2007) and Ahmed et al. (2008-2009, 2008a). Specimens available at Dhaka University Salar Khan Herbarium (DUSH) and Bangladesh National Herbarium were also consulted for the identification of the collected plants which were deposited later on in the DUSH.

\section{Results and Discussion}

In the present ethno-medico-botanical survey, a total of 56 species under 30 families were recorded. The species were related with 70 formularies (treatment mode) and for the treatment of 32 ailments. For each species botanical name, local name, family, ailments to be treated, mode of treatment, and part(s) used are provided in Table 1. After consulting Yusuf et al. (2009) and Ghani (1998), Citrus limon (L.) Burm. f., C. maxima (Burm.) Merr., Cucurbita pepo L., Lepisanthes rubiginosa (Roxb.) Leenh., Euphorbia pulcherrima Willd. ex Klotz., Mimosa diplotricha C. Wright ex Sauv. have been recorded as new medicinal plants for the first time in Bangladesh.

Distribution of medicinal plant species in the families shows variation (Fig. 1). Rutaceae is represented by six species and each of Lamiaceae and Euphorbiaceae is represented by four species. A single species in each was recorded by 19 families while two species in each was recorded by four families. Zingiberaceae, Solanaceae, Combritaceae, Caesalpiniaceae and Asteraceae were represented by two species in each. The survey indicated that the common medicinal plant families in the study area are Rutaceae, Lamiaceae, Euphorbiaceae, Solanaceae, Zingiberaceae, Combretaceae, Asteraceae, Caesalpiniaceae, Lauraceae, Mimosaceae, Meliaceae, and Cucurbitaceae. This findings of common medicinal plant families in the study is in agreement with Yusuf et al. (2009) and Ghani (1998).

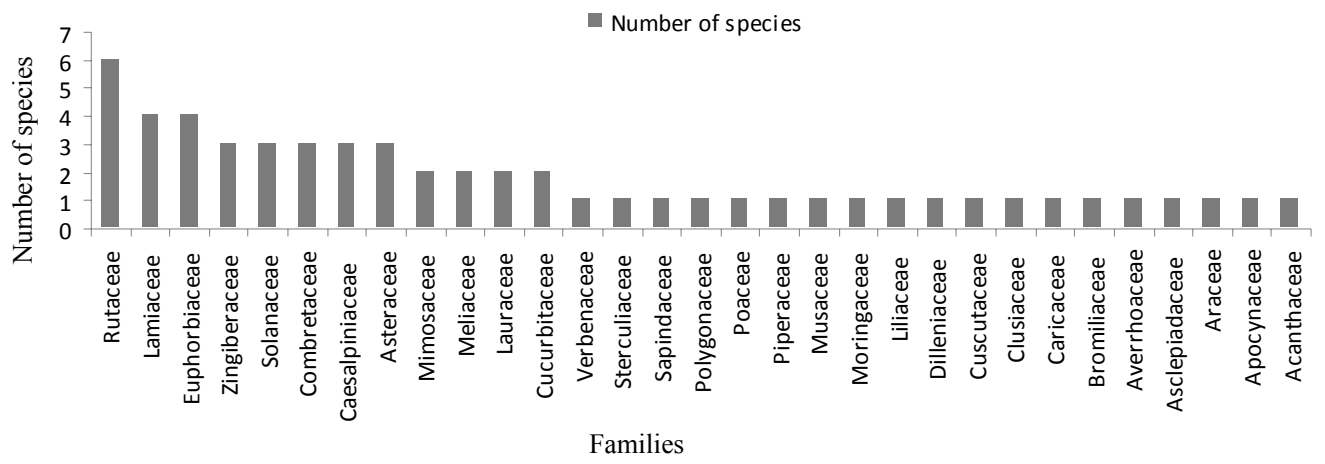

Fig. 1. Distribution of species amomng different families.

Analysis of the data based on habits showed that leading medicinal plant species $39.29 \%$ belonged to herbs, $19.64 \%$ shrubs, $35.71 \%$ trees and $5.36 \%$ climbers (Table 1). Giday (2001) reported that herb is the leading medicinal species in his article on Zay people of Ethiopia whereas Teklehamymanot and Giday (2007) reported same result among the people of Zegie Peninsula, Northwestern Ethiopia. The present report on leading medicinal species as herb, is similar to the above findings. 
ETHNO-MEDICO-BOTANICAL STUDY IN LAWACHARA

Table 1. List of plants and their diversity in use for medicinal purposes by the people living in and around Lawachara National Park.

\begin{tabular}{|c|c|c|c|c|c|c|}
\hline $\begin{array}{l}\text { Name of } \\
\text { species/plants }\end{array}$ & $\begin{array}{l}\text { Local } \\
\text { name }\end{array}$ & Habit & $\begin{array}{l}\text { Name of } \\
\text { family }\end{array}$ & $\begin{array}{l}\text { Part (s) } \\
\text { used }\end{array}$ & Ailments & $\begin{array}{l}\text { Treatment } \\
\text { process }\end{array}$ \\
\hline $\begin{array}{l}\text { Adhatoda zeylanica } \\
\text { Medikus }\end{array}$ & Bashok & Shrub & Acanthaceae & $\mathrm{L}$ & Cough, flue & Taken leaves juice \\
\hline $\begin{array}{l}\text { Aegle marmelos (L.) } \\
\text { Corr. }\end{array}$ & Haigakok & Tree & Rutaceae & $\mathrm{F}$ & $\begin{array}{l}\text { Dysentery, } \\
\text { stomachache }\end{array}$ & $\begin{array}{l}\text { Taken green fruits, } \\
\text { also taken ripe } \\
\text { fruits }\end{array}$ \\
\hline Alium сера L. & Piaj & Herb & Liliaceae & $\mathrm{L}$ & Cold & $\begin{array}{l}\text { Applied juice on } \\
\text { head }\end{array}$ \\
\hline $\begin{array}{l}\text { Alstonia scholaris (L.) } \\
\text { R. Br. }\end{array}$ & Chatim & Tree & Apocynaceae & $\mathrm{LA}, \mathrm{L}$ & $\begin{array}{l}\text { Joint pain, } \\
\text { cold, fever }\end{array}$ & $\begin{array}{l}\text { Applied latex, also } \\
\text { taken leaves juice }\end{array}$ \\
\hline $\begin{array}{l}\text { Ammomum aromaticum } \\
\text { Roxb. }\end{array}$ & Taragota & Herb & Zingiberaceae & SD & Fever & Taken seed juice \\
\hline $\begin{array}{l}\text { Ananas sativus (Lindl.) } \\
\text { Merr. }\end{array}$ & Anaros & Herb & Bromeliaceae & $\mathrm{F}$ & $\begin{array}{l}\text { Jaundice, } \\
\text { anthelmintics }\end{array}$ & Taken fruits \\
\hline Averrhoa carambola L. & Kamranga & Tree & Oxalidaceae & $\mathrm{L}, \mathrm{F}$ & $\begin{array}{l}\text { Blood } \\
\text { pressure }\end{array}$ & $\begin{array}{l}\text { Applied both } \\
\text { leaves and fruits } \\
\text { juice }\end{array}$ \\
\hline $\begin{array}{l}\text { Azadirachta indica A. } \\
\text { Juss. }\end{array}$ & Neem & Tree & Meliaceae & $\mathrm{L}, \mathrm{F}$ & $\begin{array}{l}\text { Pox, skin } \\
\text { diseases, } \\
\text { stomachache, } \\
\text { anthelmintics, } \\
\text { tooth brush, } \\
\text { toothache, } \\
\text { good health }\end{array}$ & $\begin{array}{l}\text { Leaves boiled with } \\
\text { water and apply } \\
\text { physically, both } \\
\text { leaves and fruits } \\
\text { juice taken and } \\
\text { tablet made by } \\
\text { leaves paste }\end{array}$ \\
\hline $\begin{array}{l}\text { Cajanus cajan (L.) } \\
\text { Millsp. }\end{array}$ & Orhor & Shrub & Caesalpiniaceae & $\mathrm{L}$ & Jaundice & Leaves juice taken \\
\hline $\begin{array}{l}\text { Calotropis procera } \\
\text { (Ait.) R. Br. }\end{array}$ & Akanda & Shrub & Asclepiadaceae & $\mathrm{L}$ & Abscess & $\begin{array}{l}\text { Applied leaves } \\
\text { juice }\end{array}$ \\
\hline Capsicum frutescens L. & Morich & Herb & Solanaceae & $\mathrm{F}$ & Cut injury & $\begin{array}{l}\text { Paste of dry } \\
\text { capsicum plus hot } \\
\text { mustard oil } \\
\text { applied }\end{array}$ \\
\hline Carica papaya L. & Kaiphal & Tree & Caricaceae & LA & Ring worm & $\begin{array}{l}\text { Applied latex of } \\
\text { green fruits }\end{array}$ \\
\hline $\begin{array}{l}\text { Centella asiatica }(\mathrm{L} .) \\
\text { Urban }\end{array}$ & Peruk & Herb & Clusiaceae & WP & $\begin{array}{l}\text { Dysentery, } \\
\text { stomachache }\end{array}$ & $\begin{array}{l}\text { Taken whole plant } \\
\text { by cooking, also } \\
\text { taken juice from } \\
\text { whole plant }\end{array}$ \\
\hline $\begin{array}{l}\text { Cinnamomum tamala } \\
\text { Nees \& Aberm. }\end{array}$ & Daruchini & Tree & Lauraceae & $\mathrm{B}$ & Headache & Chewing bark \\
\hline $\begin{array}{l}\text { Citrus aurantifolia } \\
\text { (Chrim. \& Panzer) } \\
\text { Swingle }\end{array}$ & Lebu & Shrub & Rutaceae & $\mathrm{F}$ & Fever & $\begin{array}{l}\text { Applied fruit juice } \\
\text { on head }\end{array}$ \\
\hline C. limon (L.) Burm. f. & Guralebu & Tree & Rutaceae & $\mathrm{F}$ & Jaundice & Taken fruits juice \\
\hline $\begin{array}{l}\text { C. maxima (Burm.) } \\
\text { Merr. }\end{array}$ & Jambura & Tree & Rutaceae & $\mathrm{F}$ & Headache & Fruit juice taken \\
\hline $\begin{array}{l}\text { Clerodendrum } \\
\text { viscosum Vent. }\end{array}$ & Bhait & Shrub & Verbenaceae & $\mathrm{L}$ & $\begin{array}{l}\text { Stomachache, } \\
\text { toothache }\end{array}$ & $\begin{array}{l}\text { Taken leaves juice } \\
\text { with sugar, also } \\
\text { taken juice of } \\
\text { young leaves }\end{array}$ \\
\hline
\end{tabular}


(Contd.)

\begin{tabular}{|c|c|c|c|c|c|c|}
\hline $\begin{array}{l}\text { Coccinia cordifolia } \\
\text { Cogn. }\end{array}$ & Kaoaluli & Climber & Cucurbitaceae & $\mathrm{L}$ & Cold, cough & Taken leaves juice \\
\hline $\begin{array}{l}\text { Colocasia esculenta } \\
\text { (L.) Schott }\end{array}$ & Kachu & Herb & Araceae & $\mathrm{S}$ & $\begin{array}{l}\text { Insects bite, } \\
\text { cut injury }\end{array}$ & Applied stem juice \\
\hline Cucurbita pepo L. & Lao & Climber & Cucurbitaceae & $\mathrm{S}$ & $\begin{array}{l}\text { Tooth } \\
\text { infection }\end{array}$ & $\begin{array}{l}\text { Stem decoction for } \\
\text { gargling }\end{array}$ \\
\hline $\begin{array}{l}\text { Curcuma domestica } \\
\text { Valet. }\end{array}$ & Halud & Herb & Zingiberaceae & $\mathrm{R}$ & $\begin{array}{l}\text { Rheumatic } \\
\text { pain, cut } \\
\text { injury }\end{array}$ & $\begin{array}{l}\text { Paste of raw } \\
\text { turmeric applied }\end{array}$ \\
\hline Cuscuta reflexa Roxb. & Sunnalata & Herb & Cuscutaceae & $\mathrm{S}$ & Anthelmentics & Taken juice of stem \\
\hline $\begin{array}{l}\text { Cynodon dactylon (L.) } \\
\text { Pers. }\end{array}$ & Durba & Herb & Poaceae & WP & Cut injury & $\begin{array}{l}\text { Applied juice of } \\
\text { whole plants }\end{array}$ \\
\hline Datura metel L. & Dutura & Shrub & Solanaceae & $\mathrm{L}$ & $\begin{array}{l}\text { Toothache, } \\
\text { abscess }\end{array}$ & $\begin{array}{l}\text { Applied leaves } \\
\text { juice with ghee }\end{array}$ \\
\hline Dillenia indica L. & Chalta & Tree & Dilleniaceae & $\mathrm{F}$ & Hair tonic & $\begin{array}{l}\text { Applied juice of } \\
\text { fruits }\end{array}$ \\
\hline $\begin{array}{l}\text { Eupatorium odoratum } \\
\text { L. }\end{array}$ & Pisaish & Herb & Asteraceae & $\mathrm{L}$ & Cut injury & $\begin{array}{l}\text { Leaves juice } \\
\text { applied }\end{array}$ \\
\hline Euphorbia hirta L. & Dudia & Herb & Euphorbiaceae & $\mathrm{L}$ & $\begin{array}{l}\text { Bronchitis, } \\
\text { cough }\end{array}$ & Taken leaves juice \\
\hline $\begin{array}{l}\text { E. pulcherrima Willd. } \\
\text { ex Klotz }\end{array}$ & Lalpata & Shrub & Euphorbiaceae & $\mathrm{L}$ & Cut injury & Taken leaves juice \\
\hline $\begin{array}{l}\text { Glycosmis arborea } \\
\text { (Roxb.) A. DC. }\end{array}$ & Bonjamir & Shrub & Rutaceae & $\mathrm{L}$ & $\begin{array}{l}\text { Flue, cough, } \\
\text { fever }\end{array}$ & Taken leaves juice \\
\hline $\begin{array}{l}\text { Hyptis suaveolens (L.) } \\
\text { Poit. }\end{array}$ & Tokma & Herb & Lamiaceae & SD & Appetizer & $\begin{array}{l}\text { Taken seed mixed } \\
\text { with juice of bark } \\
\text { of Sterculia foetida }\end{array}$ \\
\hline $\begin{array}{l}\text { Lepisanthes rubiginosa } \\
\text { (Roxb.) Leenh. }\end{array}$ & Chagalnadi & Tree & Sapindaceae & $\mathrm{L}$ & Fever & Taken leaves juice \\
\hline $\begin{array}{l}\text { Leucas lavandulaefolia } \\
\text { Smith }\end{array}$ & Dhandakolosh & Herb & Lamiaceae & $\mathrm{L}$ & Lactation & $\begin{array}{l}\text { Taken as fried } \\
\text { leaves }\end{array}$ \\
\hline $\begin{array}{l}\text { Litsea glutinosa (Lour.) } \\
\text { Robinson }\end{array}$ & Chengpisla & Tree & Lauraceae & $\mathrm{L}, \mathrm{B}$ & $\begin{array}{l}\text { Dysentery, } \\
\text { mental peace, } \\
\text { menstruation, } \\
\text { headache }\end{array}$ & $\begin{array}{l}\text { Both leaves and } \\
\text { bark juice taken, } \\
\text { also applied juice } \\
\text { of bark }\end{array}$ \\
\hline Melia azedarach L. & Goraneem & Tree & Meliaceae & $\mathrm{L}$ & $\begin{array}{l}\text { Fever, } \\
\text { anthelmintics }\end{array}$ & Leaves juice taken \\
\hline $\begin{array}{l}\text { Mikania cordata } \\
\text { (Burm.) Robinson }\end{array}$ & Refugeelata & Climber & Asteraceae & $\mathrm{L}$ & Cut injury & $\begin{array}{l}\text { Applied leaves } \\
\text { juice }\end{array}$ \\
\hline $\begin{array}{l}\text { Mimosa diplotricha C. } \\
\text { Wright ex Sauv. }\end{array}$ & Sadalaizzabati & Herb & Mimosaceae & $\mathrm{L}$ & Skin diseases & $\begin{array}{l}\text { Leaf decoction } \\
\text { applied physically }\end{array}$ \\
\hline M. pudica L. & Ukhainthabi & Herb & Mimosaceae & $\mathrm{L}$ & $\begin{array}{l}\text { Cut injury, } \\
\text { toothache }\end{array}$ & $\begin{array}{l}\text { Applied leaves } \\
\text { juice, decoction for } \\
\text { gargling }\end{array}$ \\
\hline Moringa oleifera Lamk. & Shajna & Tree & Moringaceae & $\mathrm{S}, \mathrm{B}$ & $\begin{array}{l}\text { Cold, } \\
\text { bodyache }\end{array}$ & $\begin{array}{l}\text { Taken stem juice } \\
\text { mixed sugar, also } \\
\text { taken fired bark } \\
\text { with turmeric }\end{array}$ \\
\hline
\end{tabular}


(Contd.)

\begin{tabular}{|c|c|c|c|c|c|c|}
\hline Musa paradisiaca $\mathrm{L}$. & Kala & Herb & Musaceae & $\mathrm{L}, \mathrm{F}$ & $\begin{array}{l}\text { Cut injury, } \\
\text { diarrhoea and } \\
\text { dysentery }\end{array}$ & $\begin{array}{l}\text { Applied leaves } \\
\text { base, also taken } \\
\text { paste of green } \\
\text { fruits }\end{array}$ \\
\hline $\begin{array}{l}\text { Ocimum americanum } \\
\text { L. }\end{array}$ & Rozetpata & Herb & Lamiaceae & $\mathrm{L}$ & Bronchitis & Leaves juice taken \\
\hline O. sanctum $\mathrm{L}$. & Tulsi & Herb & Lamiaceae & $\mathrm{L}$ & $\begin{array}{l}\text { Flue, cough, } \\
\text { ring warm }\end{array}$ & $\begin{array}{l}\text { Taken leaves juice, } \\
\text { also applied leaves } \\
\text { paste with salt }\end{array}$ \\
\hline $\begin{array}{l}\text { Persicaria hydropiper } \\
\text { (L.) Spach }\end{array}$ & Kukragach & Herb & Polygonaceae & $\mathrm{L}$ & Insects bite & $\begin{array}{l}\text { Applied leaves } \\
\text { juice }\end{array}$ \\
\hline Phyllanthus emblica L. & Aolagota & Tree & Euphorbiaceae & $\mathrm{F}$ & Appetizer & Taken fruits \\
\hline Piper betel L. & Pan & Herb & Piperaceae & $\mathrm{L}$ & $\begin{array}{l}\text { Cut injury, } \\
\text { pain waiver, }\end{array}$ & $\begin{array}{l}\text { Leaves juice } \\
\text { applied }\end{array}$ \\
\hline Psidium guajava L. & Peara & Tree & Rutaceae & $\mathrm{L}$ & Dysentery & $\begin{array}{l}\text { Taken both young } \\
\text { leaves juice added } \\
\text { with sugar }\end{array}$ \\
\hline Ricinus communis L. & Uripata & Shrub & Euphorbiaceae & $\mathrm{L}$ & $\begin{array}{l}\text { Ring worm, } \\
\text { abscess }\end{array}$ & $\begin{array}{l}\text { Applied leaves } \\
\text { juice with salt }\end{array}$ \\
\hline Senna alata (L.) Roxb. & Dadmordan & Shrub & Caesalpiniaceae & $\mathrm{L}$ & Ring worm & $\begin{array}{l}\text { Applied leaves } \\
\text { juice }\end{array}$ \\
\hline Solanum melongena $\mathrm{L}$. & Begun & Shrub & Solanaceae & $\mathrm{F}$ & Pain waiver & $\begin{array}{l}\text { Paste of fruit } \\
\text { applied }\end{array}$ \\
\hline Spilanthes calva DC. & Nakful & Herb & Asteraceae & I & Tooth pain & $\begin{array}{l}\text { Chewing } \\
\text { inflorescence }\end{array}$ \\
\hline Sterculia foetida L. & Udal & Tree & Steculiaceae & B & Stomachache & $\begin{array}{l}\text { Taken juice of bark } \\
\text { mixed with sugar }\end{array}$ \\
\hline Tamarindus indica L. & Tentul & Tree & Caesalpiniaceae & $\mathrm{F}$ & Abscess & $\begin{array}{l}\text { Applied as paste } \\
\text { with tamarind, } \\
\text { betel leaves }\end{array}$ \\
\hline $\begin{array}{l}\text { Terminalia arjuna } \\
\text { (Roxb. ex DC.) Wight } \\
\text { \& Arn. }\end{array}$ & Arjun & Tree & Combretaceae & F, B & $\begin{array}{l}\text { Stomachache, } \\
\text { cough }\end{array}$ & $\begin{array}{l}\text { Juice of fruits } \\
\text { added with sugar, } \\
\text { also taken juice of } \\
\text { bark with honey }\end{array}$ \\
\hline $\begin{array}{l}\text { T. bellirica (Gaertn.) } \\
\text { Roxb. }\end{array}$ & Bohera & Tree & Combretaceae & $\mathrm{F}$ & Constipation & $\begin{array}{l}\text { Taken juice of } \\
\text { fruits }\end{array}$ \\
\hline T. chebula Retz. & Horitaki & Tree & Combretaceae & $\mathrm{F}$ & $\begin{array}{l}\text { Appetizer, } \\
\text { constipation, } \\
\text { urinary } \\
\text { disorder }\end{array}$ & $\begin{array}{l}\text { Chewing fruits, } \\
\text { also taken juice of } \\
\text { fruits added with } \\
\text { sugar }\end{array}$ \\
\hline $\begin{array}{l}\text { Zingiber officinale } \\
\text { Rosc. }\end{array}$ & Ada & Herb & Zingiberaceae & $\mathrm{R}$ & $\begin{array}{l}\text { Flue and } \\
\text { bronchitis }\end{array}$ & $\begin{array}{l}\text { Taken zinger with } \\
\text { betel leaf and also } \\
\text { taken as syrup }\end{array}$ \\
\hline
\end{tabular}

$\mathrm{L}=$ Leaf, $\mathrm{LA}=$ Latex, $\mathrm{S}=$ Stem, $\mathrm{SD}=$ Seed, $\mathrm{F}=$ Fruit, $\mathrm{WP}=$ Whole plant, $\mathrm{B}=$ Bark, $\mathrm{R}=$ Rhizome.

Use of plant parts as medicine shows variation. Leaves are the leading part used in a majority of medicinal plants followed by fruits, bark, stem, seeds, whole plant, latex, rhizome and inflorescence (Fig. 2). Harvesting leaves for medicinal use has also been reported from Southern Ethiopia (Yirga 2010). Herbal preparation that involves roots, rhizomes, bulbs, barks, stems or whole plants affects mother plants (Dawit and Ahadu 1993). In the present study area this threat was minimal as leaves were the leading plant parts used for medicinal purposes. It was observed 
that the collection of bark as medicinal part from the wild were not sustainable. According to local people, this type of activity is carried out by the collectors related to illegal trade of medicinal plants. Litsea glutinosa and Sterculia foetida are vulnerable to this kind of activity in the study area.

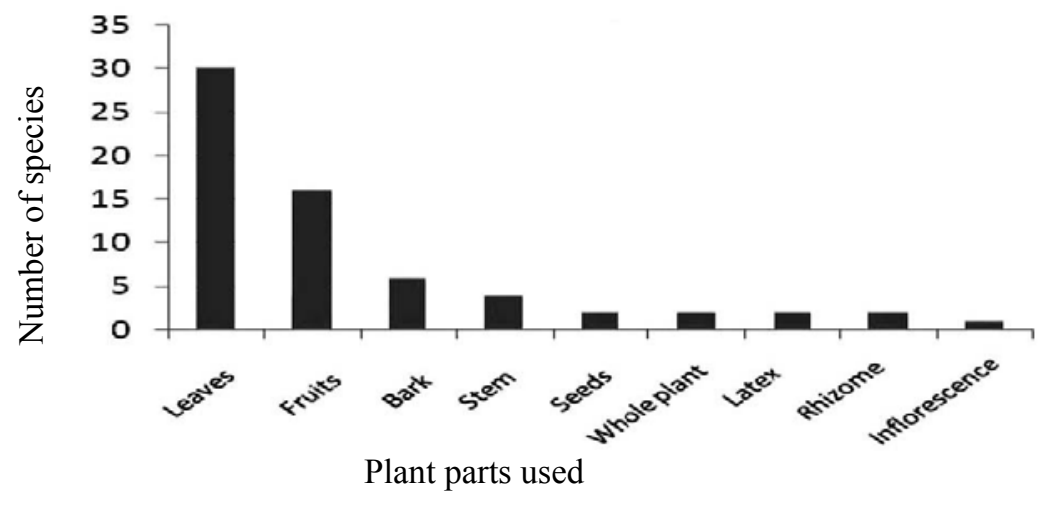

Fig. 2. Number of plant parts used for medicinal purpose.

The survey has also recorded 32 categories of uses of 56 medicinal plants (Fig. 3). This is the indication of rich knowledge of medicinal uses of plants by the local people in the area. Among them, ten species were used to cure cut injury, six species for each of toothache, stomachache, cough, and fever and five species for dysentery. Twelve categories of ailments were treated by two to four species and other fourteen categories of ailments were treated by only one species. Use of species in different ailments showed also variations. Neem (Azadirachta indica) has been used for the treatment of 7 ailments and Litsea glutinosa for 4 ailments and each of Glycosmis arborea, Musa paradisiaca, Ocimum sanctum and Terminalia chebula for 3 ailments. For treating at least two ailments 22 species were used. The remaining 28 species of the total were used for the treatment of a single ailment (Table 1). Among the medicinal use of plants, the survey reported a good number of new uses those were not mentioned in the previous literatures (Yusuf et al. 2009, Ghani 1998).

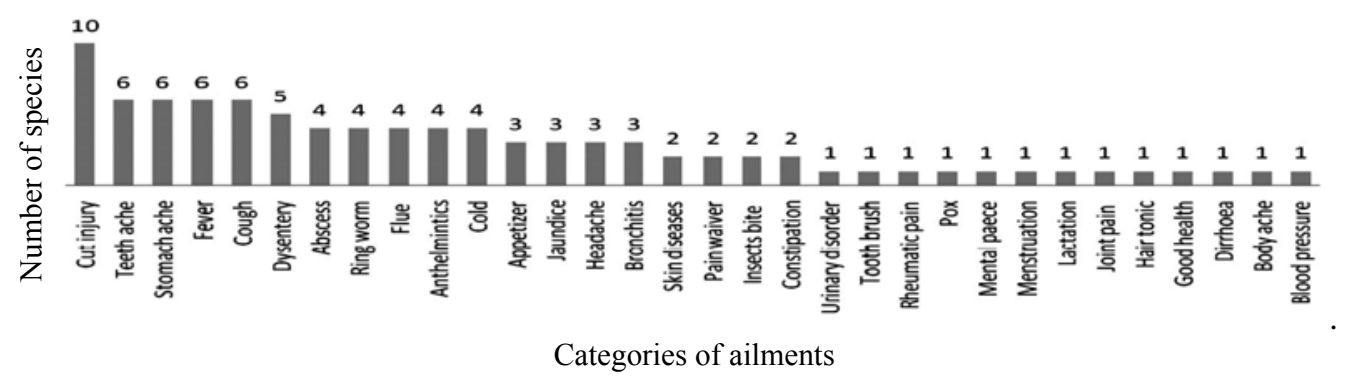

Fig. 3. Number of medicinal plants used in different categories of ailments.

The present findings are probably the first record of ethno-medicinal knowledge for Lawachara National Park using standard research protocols. The present study may be a preliminary contribution to the ethno-botany of this area using standard research methods, 
focusing on medicinal plants and their local uses for the health care. One ethnic group Khasia has been living within Magurchara and Lawachara Punji (slam) of the park area. In most cases they use medicinal plants for their primary health care. This health care knowledge transmitted orally from one generation to generation. No written documents were found in the area during the study period. The study also suggested that the present information on medicinal use of plants by the local people may be used for the park management plan and in ethno-pharmacological research in future for the discovery of new sources of drugs.

\section{Acknowledgements}

The authors are thankful to the Centre for Advanced Studies and Research in Biological Sciences, University of Dhaka for a partial financial support for the field work. The authors also wish to thank to all the informants who contributed to this study with their knowledge, friendship and co-operations.

\section{References}

Ahmed ZU, ZNT Begum, MA Hassan, M Khondker, SMH Kabir, M Ahmad, ATA Ahmed, AKA Rahman and EU Haque (Eds). 2008 - 2009. Encyclopedia of Flora and Fauna of Bangladesh. 6-10. Angiosperms; Dicotyledons. Asiat. Soc. Bangladesh, Dhaka.

Ahmed ZU, ZNT Begum, MA Hassan, M Khondker, SMH Kabir, M Ahmad, ATA Ahmed, AKA Rahman and EU Haque (Eds). 2008a. Encyclopedia of Flora and Fauna of Bangladesh. 12. Angiosperms; Monocotyledons. Asiat. Soc. Bangladesh, Dhaka.

Ahsan MF 2000. Socio-Ecology of the Hoolock Gibbon (Hylobates hoolock) in two Forests of Bangladesh. Field Research. 284-299 pp.

Ahsan MM 2007. Perceptions of tourism by indigenous communities living in and adjoining Lawachara National Park. In: Making conservation work: linking rural livelihoods and protected areas management in Bangladesh. Fox J, BR Bushley, S Dutt and SA Quazi (Eds). pp. 131-148. East-West Centre and Nishorgo Program of the Bangladesh Forest Department.

Alam MK 1988. Annotated checklist of the woody flora of Sylhet forests. Bull. 5. Plant Taxonomy Series. Bangladesh Forest Research Institute, Chittagong. 153 pp.

Alexiades MN (Ed) 1996. Selected Guidelines for Ethno Botanical Research: A Field Manual. The New York Botanical Garden, New York

Canonizado JA and SM Rahman 1998. GOB/WB Forest resources management project technical asistance component: integrated forest management plan for the Sylhet forest division. Mandala Agricultural Development Corporation and Forest Department, Ministry of Environment and Forest, Dhaka, Bangladesh. 1-4 pp.

Dawit A and A Ahadu 1993. Medicinal plants and enigmatic health practice of North Ethiopia, Berhanina Selam Printing Enterprise, Addis Ababa, Ethiopia.

Dean JP and WF Whyte 1959. How do you know if the informant is telling truth? Human Organization 17: 34-38.

Ghani A 1998. Medicinal plants of Bangladesh: Chemical constituents and uses. Asiat. Soc. Bangladesh, Dhaka. 460 pp.

Giday M 2001. An ethnobotanica study of medicinal plants used by the Zay people in Ethiopia. CBM:s skriftserie 3: 81-99.

Green MJB 1990. IUCN Directory of South Asian protected areas. IUCN The Wrold Conservation Union, Gland, Switzerland and Cambridge, UK. 24-30 pp.

Hyland BPM 1972. A technique for collecting botanical specimens in rain forest. Flora Malesiana Bulletin 26: 2038-2040.

Khan MS, MA Hassan and MZ Uddin 2002. Ethnobotanical survey in Rema-Kalenga Wildlife Sanctuary (Habiganj) in Bangladesh. Bangladesh J. Plant Taxon. 9(1): 51-60. 
Martin GJ 1995. Ethnobotany: A Methods Manual. Chapman \& Hall, London.

Riadh SM 2007. Assessing the role of non-timber forest products in the livelihoods of communities living inside and outside of Lawachara National Park. In: Making conservation work: linking rural livelihoods and protected areas management in Bangladesh, Fox J, BR Bushley, S Dutt and SA Quazi (Eds). pp. 3649. East-West Centre and Nishorgo Program of the Bangladesh Forest department.

Siddiqui KU, MA Islam, ZU Ahmed, ZNT Begum, MA Hassan, M Khondker, MM Rahman, SMH Kabir, M Ahmad, ATA Ahmed, AKA Rahman and EU Haque (Eds) 2007. Encyclopedia of Flora and Fauna of Bangladesh. 11. Angiosperms; Monocotyledons. Asiatic Society of Bangladesh, Dhaka.

Teklehamymanot T and M Giday 2007. An ethnobotanical study of medicinal plants used by the people in Zegie Peninsula Northwestern Ethiopia. J. Ethnobiol. and Ethnomed. 3:12 doi:10.1186/1746-4269-3-12

Uddin M. S Roy, MA Hassan and MM Rahman 2008. Medicobotanical report on the Chakma people of Bangladesh. Bangladesh J. Plant Taxon. 15(1): 67-72

Uddin MZ amd S Roy 2007. Collection and Management of Selected Medicinal Plants in Rema-Kalenga Wildlife Sanctuary. In: Making Conservation Work: Linking rural livelihoods and protected area management in Bangladesh, Fox J, BR Bushley, S Dutt and SA Quazi (Eds). pp. 66-83. Monograph of East-West Center, Hawaii, USA.

Uddin MZ and MA Hassan 2004. Flora of Rema-Kalenga Wildlife Sanctuary. IUCN Bangladesh Country Office, Dhaka, Bangladesh. 120 pp.

Uddin MZ, MA Hassan and M Sultana 2006. Ethnobotanical survey of medicinal plants in Phulbari Upazila of Dinajpur District, Bangladesh. Bangladesh J. Plant Taxon. 12(1): 63-68.

Uddin MZ, MS Khan and MA Hassan 2001. Ethno medical plants records of Kalenga forest range (Habiganj), Bangladesh for malaria, jaundice, diarrhea and dysentery. Bangladesh J. Plant Taxon. 8(1): 101-104.

Uddin SN, MZ Uddin, MA Hassan and MM Rahman 2004. Preliminary ethno-medical plant survey in Khagrachari district, Bangladesh. Bangladesh J. Plant Taxon. 11(2): 39-48.

Yirga G 2010. Ethnobotanical study of medicinal plants in and around Almata, Southern Tigray, Northern Ethiopia. Curr. Res. J. Biol. Sci. 2(5): 338-344.

Yusuf M, J Begum, MN Hoque and JU Choudhury 2009. Medicinal plants of Bangladesh-Revised and enlarged. Bangladesh Coun. Sci. Ind. Res. Lab. Chittagong, Bangladesh.794 pp.

(Manuscript received on15 April, 2012; revised on 2 May, 2012) 